\title{
Comparative evaluation of happy seeder technology versus normal sowing in wheat ( Triticum aestivum) in adopted village Killi Nihal Singh of Bathinda district of Punjab
}

\author{
Gurmeet Singh Dhillon \\ Punjab Agricultural University, Krishi Vigyan Kendra, Dabwali road, Bathinda - 151001 (Punjab), INDIA \\ E-mail: kvkdhillon@gmail.com
}

Received: February 28, 2016; Revised received: October 12, 2016; Accepted: December 7, 2016

\begin{abstract}
Paddy- wheat crop rotation is dominant in the Punjab state covering about 28.40 lakh hectares of cultivable land. This paddy-wheat rotation also assesses the potential of new technology i.e. happy seeder technology to address the problem. The straw management system should be necessary for all the combine harvesters. The total 28 field demonstrations on happy seeder technology were conducted in village Killi Nihal Singh of district Bathinda of Punjab state during the years 2013-14 \& 2014-15.The results showed that by using this technology, the nutrients i.e Urea, DAP and Potash fertilizer were saved worth Rs. 424.15, Rs.366.25 and Rs.1989 respectively totaling the amount to Rs.2779.40 per hectare besides improving the physical properties over longer period of time. The highest incremental B: C ratio of happy seeder plots were 4.36 during the year 2013-14. Apart from saving the burning of the paddy straw, the happy seeder technology was able to save Rs.2311.25 per hectare over the normal sown wheat during the field preparation, sowing and management operations of the crop. In the context of burning of paddy straw, this happy seeder technology is a new initiative under taken by Krishi Vigyan Kendra Bathinda for checking of environmental pollution which will be beneficial for the society as a whole because. Bathinda district lies in the south-western region of Punjab which is not much mechanized in agriculture as compared to other districts of the state.
\end{abstract}

Keywords: Demonstrations, Happy seeder, Normal sowing, Paddy straw, Technology, Weedicides

\section{INTRODUCTION}

Residue burning is a part of the 'rice-wheat cropping system' (RWCS) that is the dominant cropping system in South Asia. This system involves growing rice and wheat in rotation throughout the year. Punjab being a small state in India has played a vital role in highest food grain production. The farmers, of Punjab state have adopted the rice-wheat crop rotation. Paddywheat crop rotation is dominant in the state covering about 28.40 lakh hectares of cultivable land. Farmers gain more profit from this system but they degraded the most of natural resources like under-ground water, soil fertility, soil fauna and flora etc. They also disturbed the agro ecosystem by incomplete biogeochemical cycles, resistance development in insect pests and diseases, reduction in soil organic matter etc. This crop rotation is supposed to produce about 40 million tonne of crop waste every year. Out of this wheat straw is mostly used as dry fodder for cattle, a small part of paddy straw is utilized in generating power at biomass thermal plants while rest about 20 million tonne of the paddy straw is set on fire in the fields. Owing to high silica content, paddy straw cannot be directly fed to animals. It has been officially stated that in Punjab state, the burning of paddy straw residue causes soil nutrient loss worth 3.85 million tonne of organic carbon, 59000 tonne nitrogen, 20000 tonne phosphorus and 34000 tonne of potassium besides severely affecting the quality of ambient air. Straw carbon, nitrogen and sulphur are completely burnt and lost to the atmosphere in the process of burning (Singh et al., 2012). These nutrients then have to be replenished through organic or inorganic fertilisers, which increase the cost of production. Punjab Agricultural University (PAU), Ludhiana, has estimated that total crop residue (paddy and wheat) contained 6 million tonne of carbon, which on burning could produce 22 million tonne of carbon dioxide. It is further estimated that 25 percent nitrogen, 30-35 percent phosphorus, 50 percent sulphur and 75 percent potash applied to the paddy crop remains in the paddy straw. Heat generated by burning paddy straw kills useful microbes in the soil leading to poor soil health and loss of soil fertility. A study conducted by the National Remote Sensing Agency indicated that paddy burning in Punjab contributed 261 giga gram (Gg; $1 \mathrm{Gg}=1,000$ metric tonne) of carbon mono dioxide, $19.8 \mathrm{Gg}$ of nitrogen oxide, and other gases to the atmosphere. Punjab Agricultural University (PAU), Ludhiana, has estimated that total crop residue (paddy and wheat) contained 6 million tonne of carbon, which on burning could produce 22 million tonne of carbon 
dioxide. paddy straw residue causes soil nutrient loss - 3.85 million tonne of organic carbon; 59,000 tonne nitrogen, 20,000 tonne phosphorus and 34,000 tonne of potassium (Singh et al., 2012).

Farmers generally burn paddy straw before wheat sowing as the cheap and easy option for residue management as spreading, removal and incorporation of paddy straw in the field are labour-intensive and expensive tasks. Biomass burning of agricultural field residue (stalks and stubble) during wheat and rice harvesting periods in the Indo-Gangetic plains is an important source of atmospheric pollution in this region (Venkataraman et al., 2006). Consequently, regional climate, and in turn crop output (Auffhammer et al., 2006), and the health (Long et al., 1998) of the population are adversely affected. What factors explain the burning of rice residue on field in Punjab, India? What are the alternatives to open field burning of rice residue in Punjab, India? Further decomposition of paddy straw delays the sowing of wheat. The delay of sowing of timely varieties of wheat after 15 November results in yield losses of $1 \%$ per day (Brar et al., 2010. To solve the problem of burning of paddy straw and late sowing of wheat, a machine called Happy seeder has been developed for in-situ management of paddy straw (Sidhu et al., 2007). The Happy Seeder is a tractormounted machine that cuts and lifts rice straw, sows wheat into the bare soil, and deposits the straw over the sown area as mulch. It therefore allows farmers to sow wheat immediately after their rice harvest without the need to burn any rice residue for land preparation. The wheat crop with happy seeder can be sown in standing stubbles of rice which avoids the preparatory tillage of the field and the crop can be sown 7-10 days earlier as compared to traditional method of sowing. Heat generated by burning paddy straw kills useful microbes in the soil leading to poor soil health and loss of soil fertility. The present paper is focussed on resource conservation technologies in basmati by introducing direct seeded rice at the farmers' field under the supervision of scientists of KVK Bathinda during 2013 -14 and 2014-15. The Happy seeder is aimed at saving of environment and enhancing soil productivity without disturbing the flora and fauna. The study was also under taken with the objectives to study the costs involved in happy seeder and normal sown wheat technology, To assess the benefits of using happy seeder in terms of productivity and returns thereof and to compare the savings of happy seeder sown wheat with normal sown wheat.

\section{MATERIALS AND METHODS}

The study was conducted in village Killi Nihal Singh of Bathinda district of Punjab. This village was adopted under the project "National Initiatives on Climate Resilient Agriculture (NICRA) in year 2010. The Krishi Vigyan Kendra Bathinda has conducted total 28
Front Line Demonstrations (FLDs) on happy seeder technology in operational village Killi Nihal Singh Wala during the the kharif season of $2014 \& 2015$ to work out the sustainability of direct seeding rice, to calculate the nutrients saved and productivity maintained thereof. The total area in the village is 810 ha out of which rice is grown in 450 ha area. The happy seeder technology fits best in the in the fields where the basmati crop is sown as itis harvested in last week of October to first fortnight of November and this period co-insides with the sowing time of wheat i.e. 25 October to 15 November as the farmers can sow their wheat crop immediately after harvesting of basmati crop as the permal varieties of rice are normally harvested earlier i.e. in the first fortnight of October. At that time the day temperature ranges between $32-37^{\circ} \mathrm{C}$ which is not favourable for sowing of wheat crop. The selected respondents were educated and were innovative farmers. These demonstrations were conducted under the supervision of KVK scientists. The grain yield was recorded from happy seeder plots as well as from farmers' fields separately to compare the performance of wheat sown with happy seeder and normal sown fields. The various preparatory tillage and other operations have been assessed at the prevailing custom hiring rates in the district to analyse the differences between normal sown and happy seeder sown wheat crop. The inputs were also assessed at the prevailing rates in the open market. The costs involved and returns thereof were compared with that of normal sown wheat crop and happy seeder sown wheat. The means, average methods and various statistical tools were used to conclude the results. Weighted averages and simple tabular analysis carried out to achieve the objectives. The nutrients saved by applying less quantity of fertilizers to the wheat crop was also calculated on the prevailing rate of fertilizers in the market.

\section{RESULTS AND DISCUSSION}

Comparative cost structure in using happy seeder and normal drill: The costs incurred in sowing of wheat crop with happy seeder as well as normal drill are discussed in table 1.The happy seeder is a machine which sow the wheat crop in standing stubbles of rice crop without ploughing after paddy harvesting. However the bundles of loose paddy straw left over after the combine harvesting get choked in seed drill, disturbing the uniform distribution of seed in the field. Thus, to assure the smooth functioning of the seed drill in the field, the loose paddy straw needs to be distributed uniformly in the field. A prerequisite for using the Happy Seeder is that loose rice straw should be spread uniformly on the field - this adds a further cost to the use of the machine As it is clear from the table 1, Rs.69 per acre was spent more while handling the paddy straw before using happy seeder over normal sown fields. The cost worth Rs.405 per acre was spent for 
Table 1. Costs involved in happy seeder and normal sown wheat (Rs/Ac).

\begin{tabular}{|c|c|c|c|c|c|c|c|}
\hline \multirow[t]{2}{*}{$\begin{array}{l}\text { S. } \\
\text { N. }\end{array}$} & \multirow[t]{2}{*}{ Operation } & \multicolumn{2}{|c|}{$\begin{array}{l}\text { Year 2013-14 } \\
\text { Amount (Rs.) }\end{array}$} & \multicolumn{2}{|c|}{$\begin{array}{l}\text { Year 2014-15 } \\
\text { Amount (Rs.) }\end{array}$} & \multicolumn{2}{|c|}{ Mean } \\
\hline & & $\begin{array}{l}\text { Happy } \\
\text { seeder }\end{array}$ & $\begin{array}{l}\text { Normal } \\
\text { sown }\end{array}$ & $\begin{array}{l}\text { Happy } \\
\text { seeder }\end{array}$ & $\begin{array}{l}\text { Normal } \\
\text { sown }\end{array}$ & $\begin{array}{l}\text { Happy } \\
\text { seeder }\end{array}$ & $\begin{array}{l}\text { Normal } \\
\text { sown }\end{array}$ \\
\hline 1 & Management of loose paddy straw & 400 & 334 & 410 & 334 & 405 & 334 \\
\hline 2 & Preparatory tillage & Nil & 1100 & Nil & 1150 & Nil & 1125 \\
\hline 3 & Sowing & 300 & 250 & 300 & 250 & 300 & 250 \\
\hline 4 & Weedicide used & 250 & 380 & 250 & 410 & 250 & 395 \\
\hline \multirow[t]{3}{*}{5} & Fertilizers used & & & & & & \\
\hline & $\begin{array}{l}\text { (i) Urea } 110 \mathrm{~kg} / \mathrm{Ac} @ \text { Rs.270/bag(2014) } \\
\text { \& Rs.272/bag (2015) } \\
\text { (ii) DAP 60kg/Ac @ Rs 980/bag (2014) }\end{array}$ & 595 & 595 & 598 & 598 & 595 & 596.50 \\
\hline & \& Rs 1125/bag (2015) & 1176 & 1176 & 1350 & 1350 & 1176 & 1350 \\
\hline 6 & Irrigations -5 only labour 5 hours & 170 & 170 & 170 & 170 & 170 & 170 \\
\hline 7 & Rat control & 150 & Nil & 150 & Nil & 150 & Nil \\
\hline 8 & Insecticides and fungicides & 550 & 300 & 570 & 320 & 560 & 310 \\
\hline 9 & Harvesting with combine & 1000 & 1000 & 1500 & 1500 & 1250 & 1250 \\
\hline \multirow[t]{2}{*}{10} & Labour used 12 hours & 435 & 435 & 445 & 445 & 440 & 440 \\
\hline & Total & & & & & 5296 & 6220.50 \\
\hline
\end{tabular}

this operation under happy sown wheat crop for uniformly distribution of loose straw in the field as 1.5 labours/ acre is required for this purpose where as for normal sown wheat crop, a reaper/ cutter as is required for uniform distribution of bundled loose straw before set to fire. These findings are in accordance with the results obtained by Naresh et al. (2013). The per acre cost of reaper/cutter is Rs. 300 and it takes 1 hour labour for the burning the straw from one acre area and it costs Rs 34. Under the conventional method of wheat sowing the loose paddy straw left over by the combine harvester is burnt in the open sky. The field is then cultivated 2-3 times with discs and cultivators for seed bed preparation. On the sample farms these operations were carried out and spent Rs. 1125 per acre and this cost is nil under happy seeder sown crop as shown in table 1. Apart from this Rs.50 per acre were spent more on sowing of wheat with happy seeder over the normal seed drill. This is because the custom hiring rates of happy seeder are higher than the normal seed drills due the limited availability and higher cost price of happy seeder. There is saving of Rs. 145/acre under happy seeder sown crop as for as weedicide use s concerned because there is less emergence of weeds in crop sown with happy seeder due to coverage of paddy straw on the soil (Table 1). Fertilizers costs and irrigation costs are the same under both the conditions of wheat sowing. There is more attack of rodents in the wheat crop sown with happy seeder and there is an additional expenditure of Rs.150/for control of rodents as compared to normal sown crop. Further Rs.250 per acre was also spent more on insecticides as happy seeder sown wheat crop is more susceptible to stem borer \& this pest is controlled by applying Quinalphos (Ekalux)@ 500ml/ acre which costs Rs. 250/acre. Harvesting and labour costs are the same under both the conditions. Overall Rs. 5296 per acre were spent on different operations in the field where happy seeder was used where as Rs.6220.50 were used under the normal wheat sown conditions.

The overall comparison shows that Rs.924.50 per acre was spent more in the normal sown wheat fields over the happy seeder sown wheat. Thus, apart from saving the burning of the paddy straw the happy seeder technology was able to save Rs.2311.25 per hectare over the normal sown wheat during the field preparation, sowing and management operations of the crop. The total cost saving is estimated to be Rs $2,163 /$ ha, or Rs800/tonne, which is equivalent to a $9.4 \%$ cost saving by using happy seeder (Saunders et al., 2012) which justify the findings of the present study.

Productivity of wheat in terms of economic analysis: Different variables like seed, fertilizers, biofertilizers and pesticides were considered as critical inputs for the Happy seeder (demonstrations) as well as normal sown wheat (farmers practice) and on average an additional investment of Rs. 1105/ha were made under demonstrations (Table 2). Economic returns as a function of grain yield and MSP sale price varied during different years. Maximum returns (Rs. 74074/ha) during the year 2013-14 was obtained due to higher MSP sale rates as declared by Govt. of India. The higher additional returns and effective gain obtained under happy seeder could be due to decomposition of paddy straw which supplies the macro \& micro nutrients to the wheat crop, timely sown of crop under happy seeder by retaining the same moisture of harvesting time, improved technologies, timely operations of crop cultivations, non-monetary factors and scientific monitoring of the crop. The highest incremental $\mathrm{B}$ : $\mathrm{C}$ ratio of happy seeder plots were 4.36 during the year 2013-14. It depends on grain yield and MSP. Overall average incremental B: C ratio of happy seeder 


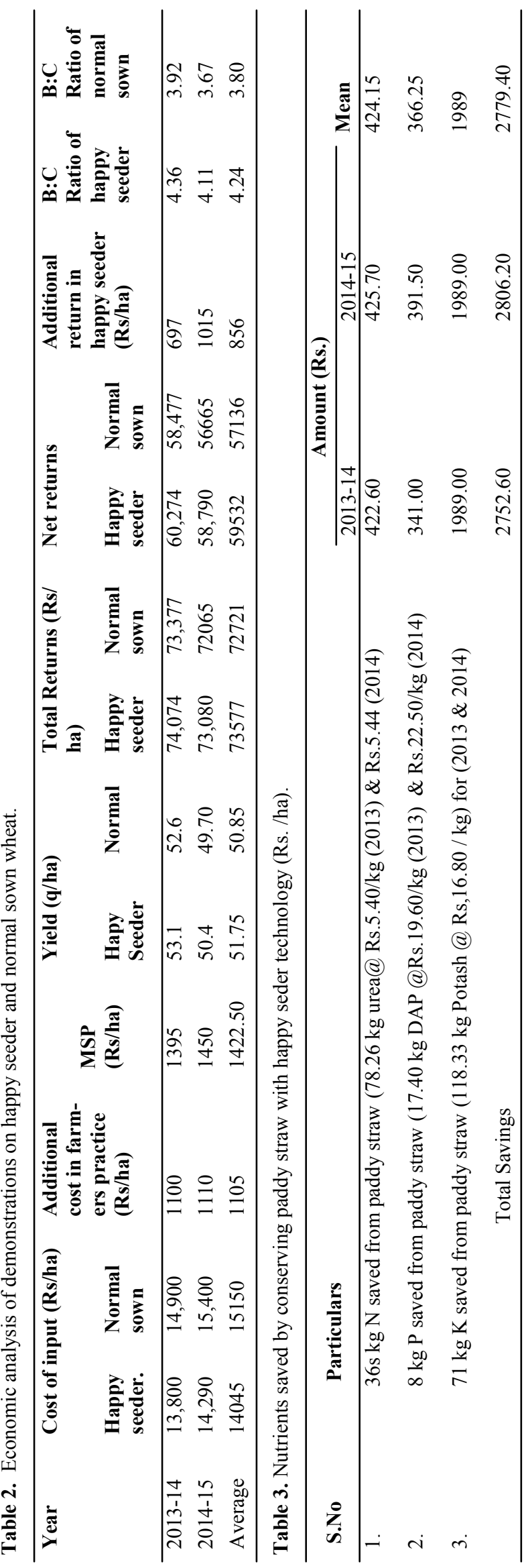

Table 4. Savings by happy seeder over normal sown wheat.

\begin{tabular}{|c|c|c|}
\hline S.N. & Particulars & $\begin{array}{l}\text { Amount } \\
\text { Rs./Acre }\end{array}$ \\
\hline 1 & $\begin{array}{l}\text { Saving on account of preparatory } \\
\text { tillage }\end{array}$ & 1125.00 \\
\hline 2. & $\begin{array}{l}\text { Gain on account of additional yield } \\
\text { of } 125 \mathrm{~kg} / \mathrm{ha} @ \text { Rs.1395 / q. } \\
(2014) \& 175 \mathrm{~kg} / \mathrm{ha} @ \text { Rs.1450/q } \\
\text { (2015)(Rs.1743+2537)/2= } \\
\text { Rs.2140/ha or Rs.1712/acre }\end{array}$ & 856.00 \\
\hline 3. & $\begin{array}{l}\text { Fertilizers saved by conserving } \\
\text { paddy straw }\end{array}$ & 1112.00 \\
\hline 4. & $\begin{array}{l}\text { Pollution check by zero smoking of } \\
\text { paddy straw }\end{array}$ & $\begin{array}{l}\text { Unaccounta- } \\
\text { ble }\end{array}$ \\
\hline ner & $\begin{array}{l}\text { Total savings of using happy seeder } \\
\text { re }\end{array}$ & 3093.00 \\
\hline
\end{tabular}

(4.24:1) was higher than average incremental B: C ratio of normal sown (3.80:1).

Although there is slight difference of yield between happy seeder sown wheat $(51.75 \mathrm{q} / \mathrm{ha})$ and normal sown wheat $(50.85 \mathrm{q} / \mathrm{ha})$ crop , but other factors like environmental safety which is un-accountable and early sowing of wheat by saving Rs.1125/ acre as preparatory tillage are also positive points of happy seeder technology. The percentage increase in yield was observed as $1.77 \%$ more than normal sown wheat. Sidhu et al. (2007) also reported $9-15 \%$ higher grain yield of wheat which was sown with happy seeder machine

Saving nutrient enriched paddy straw: The happy seeder technology was demonstrated during the year 2013-14 and 2014-15 in adopted village killi Nihal Singh district Bathinda. The loose paddy straw left over after the combine harvesting was not burnt but uniformly distributed in the same field. The wheat was then sown with the happy seeder machine. The nutrients left in the paddy straw got conserved in the field contributing towards the yield of the succeeding wheat crop as well as improving the physical properties of the soils like water retention capacity, infiltration rate, bulk density etc. the Punjab Agricultural University has estimated that 25 percent nitrogen, $30-35$ percent phosphorus, 50 percent sulphur and 75 percent potash applied to the paddy crop remains in the paddy straw. The nutrients, thus, saved have been calculated equivalent to the prevailing market price of Urea, DAP and Potash fertilizer. The paddy straw biomass added 36 kilogram nitrogen, 8 kilogram phosphorus and 71 kilogram potash in one hectare area. These nutrients, thus, saved Urea, DAP and Potash fertilizer worth Rs. 424.15, Rs.366.25 and Rs. 1989 respectively totalling the amount to Rs. 2779.40 per hectare besides improving the physical properties over longer period of time (Table 3).It could be due to the presence of paddy straw on the soil surface resulted in more availability of moisture for longer period during the growing season. Mulching has been proved to be useful in conserving 
moisture and increasing productivity in wheat (Singh et al., 2011, Li S.X et al., 2013 Pittelkow et al., 2014).

Gross savings by happy seeder technology: All the savings by the happy seeder sown wheat over the normal sown wheat were summarized in table 4 . The happy seeder technology saved during preparatory tillage, resulted in additional yield and saved nutrients by way of conserving paddy straw enriched with nitrogen, phosphorus and potash. These saving were respectively Rs.1125, Rs.856 and Rs.1120 per acre totalling to Rs.3093 per acre. Apart from above savings happy seeder saved huge amount of paddy straw from burning, checking large volume of toxic gases decreasing the green house gas effect, thus, pollution to the great extent.

\section{Conclusion}

It was concluded that rice residue is largely burnt as it is of limited value to the farmers both as livestock feed and non-feed use. Since, the machinery for planting wheat into loose rice residue was hitherto unavailable, the rice residue was burnt. The Happy Seeder technology overcomes this problem of planting wheat into the loose residue. Further happy seeder is the most efficient method to reduce the cost of production and manages the combine harvested paddy straw and ultimately improves the soil productivity over the longer period of time. This machine saved Rs.2311.00 per hectare during various operations of wheat sowing over the normal practice of burning of paddy straw followed by seed bed preparation and sowing of wheat. The results of this study also indicated that the happy seeder produced slightly higher grain yield worth Rs.2140.00 per hectare as compared to normal sown wheat, thus, proving to be profitable practice. Apart from this if paddy straw not burnt and conserved in the same field saved nutrients left over in it from the previous paddy crop worth Rs. 2779.00 per hectare. So on an average the happy seeder saved about Rs.3400 and Rs.6200 per hectare if the paddy straw is partially burnt and if not burnt but conserved in the field, respectively. Least but not the last, large volume of harmful gases and a thick smoke cover over the entire state pushing the majority of the old age population towards the dead end can also be saved.

\section{REFERENCES}

Auffhammer, M., Ramanathan, V. and Vincent, J. (2006). Integrated model shows that atmospheric brown clouds and greenhouse gases have reduced rice harvests in India, Proceedings of the National Academy of Sciences, 103(52): 19668

Brar, N.K., Jason C., Jeffrey, E. and Singh, Y. (2010). "Nitrogen management in wheat sown in rice straw as mulch in North-West India. In Proc:"19th World Congress of Soil Science, Soil Solutions for a Changing world Brisbane., Australia. August1-6, 2010, Published on DVD.

Saunders, C., Davis, L. and Pearce, D. ( 2012). Centre for international economics rice-wheat cropping systems in India and Australia, and development of the 'Happy Seeder'. ACIAR IMPACT ASSESSMENT SERIES 77 pp-27-28

Li, S.X., Wang, Z.H., LI, S.Q., Gao, Y. and Tian, X.H. (2013) Effect of plastic sheet mulch, wheat straw mulch, and maize growth on water loss by evaporation in dryland areas of China. Agricultural Water Management 116: 39-49

Long, W., Tate, W., Neuman, R., Manfreda, M., Becker, J., and Anthonisen, N. (1998). Respiratory symptoms in a susceptible population due to burning of agricultural residue, Chest, 113: 351

Pittelkow, C.M. (2014). Productivity limits and potentials of the principles of conservation agriculture. Nature 10.1038/nature13809

Naresh, R.K., Singh, S.P., Deepesh Kumar, and Bhanu Partap (2013). Experience with managing rice residues in intensive rice-wheat cropping system in North- Western India. International J. Life Sci. Biotechnology and Pharma Research, 2: 85- 96

Sidhu, H.S., Singh, M., Humphreys, E., Singh, Y., Singh, B., Dhillon, S.S., Blackwell J., Bector, V., Singh, M. and Singh, S. (2007). The happy seeder enables direct drilling of wheat in to rice stubble. Australian Journal of Experimentals Agriculture, 47: 844-854

Singh, A., Davinder, Kang, J.S. and Aggarwal, N. (2011). Management practices to mitigate the impact of high temperature on wheat: A review. Institute of Integrative Omics and Applied Biotechnology Journal, 2: 11-22

Singh, A., Kaushaland, M. and Singh, H. (2012). Improvement in productivity of wheat with crop residue and nitrogen-a review. Asian Journal of Biological and Life Sciences, 1: 139-146

Venkataraman, C., Habib, G., Kadamba, D., Shrivastava, M ., Leon, J., Crouzille, B., Boucher, O. and Streets, D. (2006). Emissions from open biomass burning in India: Integrating the inventory approach with high-resolution Moderate Resolution Imaging Spectroradiometer (MODIS) active-fire and land cover data. Global Biogeochemical Cycles, 20: 1-12 